\title{
EESTI KEELE KUI TEISE KEELE ÕPPIMINE: KAS RASKE TÖÖ VÕI KERGE LÕBU?
}

\author{
MARE KITSNIK
}

1 esti keelt teise keelena on Eestis aktiivselt õpitud ja õpetatud juba ligi kolmkümmend aastat. Vaatamata sellele on paljudel täiskasvanutel eesti keele oskusega probleeme. Centari 2018. aasta uuringu järgi ei ole pooltel muu emakeelega täiskasvanuist aktiivset eesti keele oskuse taset. Sama uuring näitab, et inimeste soov eesti keelt õppida on kõrge, kuid nende sõnul takistab õppimist eesti keele liigne raskus, vähesed võimalused eesti keeles suhelda, heade kursuste, õpetajate ja õpikute puudus, aga ka õppimisstiimuli puudumine või viitsimatus õppida. Hinnates pakutava eesti keele õppe kvaliteeti, peetakse kõige tõhusamateks suhtlemisoskust arendavaid kursusi, kuid samal ajal tunnetatakse, et kursustel pööratakse sellele osaoskusele liiga vähe tähelepanu. Õppijad väärtustavad ka aktiivõppemeetodite kasutamist eesti keele õppes ning peavad traditsioonilist grammatikaõpet üldiselt vähem oluliseks. (Centar 2018)

Seega on õppemetoodikal ja õpetajakoolitusel veel arenguruumi, et muuta eesti keel õppijaile kergemaks ning selle õppimine kaasahaaravamaks. Käesolevas artiklis arutan selle üle, milline oleks hea täiskasvanute eesti keele kursus. Arutlen, kas see peaks olema eelkõige tõsine töö, ilma milleta ei olevat võimalik head keeleoskust saavutada, kuid mis toob sageli kaasa ka eksimishirmu ja soovimatuse eesti keeles rääkida. Või võiks kursus olla süsteemse ülesehitusega, kuid tunduda osalejaile pigem kerge ja lõbusana ning tekitada neis huvi ja hasarti eesti keelt kasutada. Toetun oma arutlustes nii kognitiivlingvistika kui ka psühholoogia seisukohtadele teise keele õppe kohta.

Esiteks käsitlen autentse keele kuulmise-nägemise ja ise kasutamise olulist rolli keele omandamisel. Teiseks arutlen motivatsiooni ja positiivsete emotsioonide vajalikkuse üle õppeprotsessis ning kirjeldan mängustatudimprovisatsioonilise õppemeetodi põhimõtteid. Lõpuks vaatlen, kuidas käsitletud põhimõtteid rakendatakse täiskasvanute mängustatud-improvisatsioonilisel eesti keele kursusel.

\section{Autentse sisendi ja suhtlemise tähtsus teise keele omandamisel}

\subsection{Keel koosneb konstruktsioonidest}

Et rääkida keeleomandamisest, on vaja kõigepealt mõelda, mida peame keeleoskuseks. Traditsiooniliselt on keeleoskuse all mõistetud grammatikareeglite ja sõnavara tundmist, mis peaks iseenesest tooma kaasa ka suhtlusoskuse. Juba pool sajandit on siiski mõistetud, et grammatika- ja sõnavarateadmised ei lähe 
ise üle suhtlusoskuseks, ning on hakatud keeleoskuseks pidama kommunikatiivset keelepädevust ehk võimet keele abil erisuguseid suhtlusülesandeid täita (nt kohvikus kohvi tellida või töökoosolekul sõna võtta). Kuidas on aga suhtlusoskuse ning sõnavara ja grammatika areng omavahel täpsemalt seotud? Seda on viimasel ajal kõige rohkem uuritud Euroopa keeleõppe raamdokumendi (CEFR 2007) kommunikatiivsete keeleoskustasemete leksikaalgrammatiliste kirjelduste koostamise jaoks (vt nt English Profile). Teise keele omandamise tänapäevased uurimissuunad ei vaatle keelt enam eraldiseisva struktuurina, vaid uuritakse keelelise arengu seoseid inimese üldiste kognitiivsete võimete ja psühholoogiliste, sotsiaalsete ning kultuuriliste seaduspärasustega. Käesolevas artiklis lähenen sellele komplekssele teemale konstruktsioonigrammatika (Goldberg 1995; Croft 2001) ja keele kasutuspõhise omandamise (Larsen-Freeman 1997; Ellis 2002; Tomasello 2003; MacWhinney 2004; Eskildsen 2008) teooriatest lähtudes (vt lähemalt Kitsnik 2018: 31-41).

Konstruktsioonigrammatika järgi ei koosne keel suheldes eraldi sõnadest (nt andma, mina, raamat) ja nende kasutusreeglitest ehk grammatikast (nt käskiva kõneviisi ainsuse vorm, isikuline asesõna, alaleütlev kääne, täissihitis), vaid konstruktsioonidest - sõnade ja grammatika omavahel põimunud terviküksustest (nt anna mulle raamat). Konstruktsioonid esinevad eri keeletasanditel ja eri kujul, enamasti vaadeldakse konstruktsioonidena mitmesuguse pikkusega fraase (vt Goldberg 1995, 2003; Tomasello 2003; Eskildsen 2008; Ellis 2013). Konstruktsioonid on tekkinud inimeste mõtete-tunnete keelelisel väljendamisel sagedamini esinenud väljenduste üldistumisel. Nii on konstruktsioonis koos vorm (sõnad ja nende kujud), tähendus (kuidas keelekogukond üldiselt seda konstruktsiooni mõistab) ja kasutus (mis situatsioonis ja mis eesmärgil seda konstruktsiooni üldiselt kasutatakse). Neid osi on võimalik eristada metatasandil, kuid mitte suhtlemisel.

Konstruktsioonid võivad esineda nii konkreetsete keeletükkidena (ingl chunks) kui ka abstraktsemate skeemidena (ingl abstract patterns) (Tomasello 2000, 2003; Ellis 2002, 2003; Eskildsen 2008; Ellis, Larsen-Freeman 2009). Keeletükke (nt ma ei tea, hakkame lõpetama, ära küsi minu käest) kasutab keelekasutaja valmiskujul, ise midagi muutmata. Abstraktsemate skeemide abil saab keelekasutaja produtseerida ka selliseid väljendeid, mida ta täpselt sellisel kujul varem kuulnud-näinud pole. Näiteks poolavatud skeemi isik + ei tea abil saab produtseerida väljendusi ta ei tea, Mari ei tea, keegi ei tea jne.

Konstruktsioonid on omavahel põimunud, moodustades keeruka võrgustiku. Kui inimesed oma mõtteid väljendavad, siis panevad nad need kokku teadvuses olevatest konstruktsioonidest, mitte ei loo iga kord sõnu ja reegleid kombineerides uuesti. Seega vajab ka teise keele õppija keele sujuvaks kasutamiseks konstruktsioonide varu. Vormi-tähenduse-kasutuse terviküksusi saab omandada autentsetes suhtlussituatsioonides. Kui inimene on õppinud sõnu ja grammatikareegleid autentsetest kasutussituatsioonidest lahus, ei suuda ta vajalikus situatsioonis pahatihti keelelise väljendusega ikkagi toime tulla. Tal ei ole piisavalt automaatsust ja ta ei jõua keele osasid analüüsides neid kokku panna; samuti moodustab õppija grammatiliselt korrektseid väljendeid, mis situatsiooni ometi ei sobi. Kuidas konstruktsioonide varu kasutamine tegelikus elus realiseerub, seda mõjutavad ka isiku psühholoogilised omadused, kaaslased jm. 


\subsection{Keelekonstruktsioonide omandamine algab autentsest sihtkeele sisendist}

Kuidas teise keele õppija sihtkeele konstruktsioonivõrgustiku omandab? Kasutuspõhise teooria järgi saab see toimuda vaid autentses keelekeskkonnas keelt tajudes ja ise kasutades. Selles mõttes toimub teise keele omandamine vaatamata teatud eripärale üldjoontes sarnaste mehhanismide alusel kui laste esimese keele omandamine.

Keelekeskkonnas saab keeleomandaja kõigepealt autentse keelelise sisendi. See tähendab mingi suhtluseesmärgi saavutamiseks kasutatud keelelisi väljendeid, mida looja pole välja mõelnud õppe-eesmärgil. Selleks võib olla ka õpetaja kõne tunnis, kui ta annab tööjuhiseid või suhtleb õpilastega. Autentne sisendkeel erineb spetsiaalselt õpiku jaoks kirjutatud keelest selle poolest, et selles esineb korraga palju eri tüüpi konstruktsioone, mis pole raskuse, teemade vm järgi rühmitatud. Autentse keele konstruktsioonid on aga alati seotud konkreetsete suhtlussituatsioonidega, mis annab neile vormitähenduse-kasutuse seose. See aitab keeleomandajal konstruktsioone sihtkeele massist eristada ja mõistma hakata. Et konstruktsioone on väga palju, ei suuda inimene neist kõigist korraga aru saada, vaid see toimub järk-järgult. Mis järjekorras keeleomandaja konstruktsioone märkab ning mõistab, sõltub kindlatest faktoritest: konstruktsioonide esinemissagedusest (ingl frequency) sisendkeeles, esinemise hiljutisusest (ingl recency), esilduvusest (ingl salience) jm (Ellis 2002, 2003, 2013; Ellis, Larsen-Freeman 2009).

\subsubsection{Konstruktsioonide omandamine sõltub nende esinemissagedusest sisendkeeles}

Üheks olulisemaks omandamist mõjutavaks faktoriks on konstruktsiooni sagedus sisendkeeles. Kõigile inimkeelte võrgustikele on tüüpiline, et väike osa konstruktsioone esineb neis väga kõrge sagedusega ning ülejäänud järjest langeva sagedusega (Zipf 1949). Seega kuuleb-näeb keeleomandaja loomulikus keelekeskkonnas mõnesid konstruktsioone väga sageli ja paljusid harvem. Sagedamini esinevaid konstruktsioone töötleb aju kergemini ning inimene hakkab neid kiiremini märkama ja mõistma. Seejuures eristatakse kaht tüüpi sagedust: sõnesagedus (ingl token-frequency) ja tüübisagedus (ingl type-frequency) (Ellis 2002, 2003, 2013; Ellis, Larsen-Freeman 2009). Sõnesagedus tähendab konkreetse tervikliku keeletüki (nt ma ei tea, tule siia, mis sa arvad) sagedust keeles. Kõrge sõnesagedusega keeletükid kinnistuvad keeleomandaja teadvuses muutumatul kujul. Tüübisagedus tähendab aga konstruktsiooni abstraktse skeemi esinemissagedust. Näiteks kuuldes sageli keeletükke ma ei tea, ma ei taha, ma ei kuule, ma ei näe, hakkab keeleomandajal tekkima abstraktne skeem ma ei + tegevust väljendav sõna ilma lõputa. Keeleomandamise seisukohalt on oluline ka konstruktsiooni esinemise hiljutisus. Hiljuti keeleomandajale ilmunud konstruktsioone töötleb aju samuti kergemini ja tõhusamalt. Seega omandatakse konstruktsioonigrammatika järgi ka teist keelt levinud arusaamale vastupidises järjekorras: mitte enne üksikud sõnad ja nende kasutusreeglid ning seejärel nende kombinatsioonid, 
vaid enne kombinatsioonid, mille põhjal üldistatakse seaduspärasused (Eskildsen 2008; Martin jt 2010; Mustonen 2015). Kui teise keele omandajad õpivad keelt peamiselt traditsioonilises keeletunnis traditsiooniliste õpikute järgi, saavad nad liiga vähe autentset keelelist sisendit ja loomulikud keelekonstruktsioonid nende teadvuses ei jõua välja kujuneda (Ellis 2003).

\subsubsection{Konstruktsioonide omandamine sõltub nende esilduvusest sisendkeeles}

Kõiki sagedasi ja hiljutisi konstruktsioone ei pane keeleõppija siiski ühtemoodi tähele ega omanda samal ajal. Konstruktsiooni märkamiseks on oluline, et see oleks keeleomandaja jaoks millegi poolest suurest sisendkeele massist esilduv. Kõigepealt on oluline konstruktsiooni asukoht lauses (nt lause lõpus olevad keeleüksused on esilduvamad) ja rõhk. Esilduvust määrab ka konstruktsiooni pikkus ja tema olulisus edastatava sõnumi mõistmisel (Ellis 2013). Grammatilised tunnused kui abstraktse konstruktsiooni osad on sageli madala esilduvusega, sest need on keele evolutsioonis rohke kasutuse tõttu lühenenud ja neid töödeldakse sageli koos sõnaga tervikuna (Bybee 2000). Kui sõnum on esimese keele ja üldiste maailmateadmiste mõjul mõistetav ka ilma konstruktsiooni märkamata, siis väheneb konstruktsiooni esilduvus teise keele omandaja jaoks veelgi. Nii on näidatud, et inglise keele kui teise keele õppijate jaoks on lihtminevikku märkivad verbitunnused sageli madalama esilduvusega kui aega märkivad määrsõnad (eile, eelmisel aastal vm), mis annavad sõnumi tähenduse kergemini edasi (Ellis, Sagarra 2013).

Samuti on esilduvuse seisukohalt tähtis vormi ja tähenduse seose usaldatavus (Ellis 2013). Kui sama vorm kannab enamasti sama tähendust (nt -si kui lihtmineviku tunnus eesti verbidel, siis on see seos keeleomandaja jaoks usaldatav ja kognitiivselt kergem ning esilduvam. Kui sama vorm võib kanda erisuguseid tähendusi (nt -nud kui lihtmineviku eitava vormi tunnus ja täismineviku jaatava vormi tunnus) või kui sama tähendust esitab mitu erisugust vormi (nt mitmuse osastava lõpud -id, -sid, $-e,-i,-u$ ), on keeleomandaja jaoks vormi ja tähenduse seose usaldatavus madalam. See muudab konstruktsioonid kognitiivselt keerukamaks ja vähem esilduvaks.

Autentses sisendis madalama esilduvusega konstruktsioonide omandamise tõhusust võib tõsta konstruktsioonile teadliku tähelepanu juhtimine (Spada 1997; Schmidt 2001; Ellis 2005). Konstruktsioonile tähelepanu juhtimine võib olla nii deduktiivne (õppijale antakse reegel) kui ka induktiivne (õppijal lastakse näidiste põhjal ise reegel tuletada). Konstruktsioonide märkamine ja töötlemine on seotud kognitiivse jõuga. Keeleoskuse tõusuga muutub järjest enam konstruktsioone, sh kognitiivselt keerukamaid, keeleomandaja jaoks esilduvaks - mida suurem osa sisendkeelest on arusaadav, seda enam vabaneb kognitiivset jõudu uute nüansside märkamiseks. 


\subsection{Keelekonstruktsioonid omandatakse ise keelt kasutades}

Pärast märkamist ja mõistmist hakkab keeleomandaja proovima ka ise konstruktsioone kasutada ehk ta hakkab end kuidagi keeleliselt väljendama. Tavaliselt algab see terviklike keeletükkide katsetamisest. Üldjuhul on nendeks mingi kategooria prototüüpsed esindajad, mis on sisendkeeles sagedased ja esilduvad (Ellis, Larsen-Freeman 2009). On näidatud, et teise keele õppijad kasutavad eri verbi-argumendi struktuurides esimesena iga struktuuri jaoks prototüüpset üldise tähendusega verbi (nt inglise verbi-lokatiivi konstruktsioonis verbi go ('minema'), verbi-objekti-lokatiivi konstruktsioonis verbi put ('panema') (Ellis, Ferreira-Junior 2009)). Edasi hakatakse järk-järgult rohkem kasutama abstraktseid konstruktsiooniskeeme, mis võimaldavad asendada kõige sagedasemad verbid teistega (Clark 1978; Pinker 1989; Ninio 1999). Eesti keele kui teise keele tingiva kõneviisi arengu kohta on samuti näidatud, kuidas B1-taseme kirjalikus keeles esineb tingiv kõneviis kokku kaheksa verbiga ja neist peamiselt kahega (tahtma, saama), B2-tasemel aga juba 23 verbiga ja neist sagedamini kuuega (tahtma, pidama, olema, võima, soovima, soovitama) (Kitsnik 2018: 89). Seega arenevad keeleomandaja konstruktsioonid algsetest prototüüpsetest piiratud vormi ja tähendusega keeletükkidest aja jooksul abstraktsete konstruktsiooniskeemideni, mille alusel saab inimene ise endale vajalikke väljendusi luua.

Nii ei võta teise keele omandaja keelekogukonnalt keelt kunagi otse üle, vaid konstrueerib selle põhjal oma keelevõrgustiku. Teise keele õppijate konstruktsioonid on sageli üsna ebastabiilsed ehk sihtkeele normidega võrreldes „vigased”. Põhjuseks võib siinjuures olla nii ebapiisav keeleline sisend, esimese keele mõju kui ka vähene keele kasutus. Teist keelt õpitakse küllalt sageli formaalses keskkonnas, mis ei võimalda konstruktsioone piisavalt tajuda ega lase neil kindlalt juurduda (Ellis 2003). Esimese keele konstruktsioonivõrgustik ühelt poolt toetab teise keele õppimist, sest osa konstruktsioonitüüpe on keeltes alati sarnased (Kaivapalu 2005; Ellis 2013). Teiselt poolt segavad esimese keele konstruktsioonid kohati uue keele omandamist, nõudes olemasoleva võrgustiku ümberstruktureerimist (MacWhinney 2002, 2004).

Uuringud on näidanud, et konstruktsioonide üldised arengurajad on üsna sarnased: arenedes muutuvad õppijate konstruktsioonid nii keerukamaks, sujuvamaks kui ka täpsemaks (vt lähemalt Kitsnik 2018; Martin jt 2010; Mustonen 2015), kuid see ei toimu ühtlaselt. Kui leiab aset arenguhüpe keerukuses ehk õppijad hakkavad ise aktiivselt uusi konstruktsioone moodustama, et oma tähendusi väljendada, toob see sageli kaasa täpsuse ajutise languse. Seega võib „vigade” arvu kasv tähendada kiiret keelelist arengut, mitte halvasti õpitud keelt. Samas võib ka „vigaseid” õppijakeele konstruktsioone pidada mõnikord täieõiguslikeks. Nii on näidatud, et kui õppijate vajadus end väljendada ületab keelelised oskused, siis loovad nad ise keelekeskkonnast üles korjatud väljendite põhjal konstruktsioone, mis pole täpsed reeglipärase grammatika mõttes, kuid täidavad oma suhtlusfunktsiooni (Paavola 2008; Seilonen 2013).

Mida rohkem autentset ja motiveerivat sisendit keeleomandaja tajub ning mida rohkem saab ta ise keelt autentsetes, motiveerivates ja turvalistes suhtlussituatsioonides kasutada, seda kiiremini ta konstruktsioonid arenevad ja seda loomulikumaks need muutuvad (Mustonen 2015). Seega peaks 
keeleõppe põhisisuks olema mitte situatsioonist eraldatud keelendite õppimine ja grammatikateemade harjutamine, vaid õppijat huvitavate autentsete tekstide kuulamine-lugemine ning oma mõtete rohke väljendamine nii suuliselt kui ka kirjalikult. Keeleõppijad vajavad võimalust suhelda teiste keelekasutajatega, koostööd, tähenduste „läbirääkimist” (ingl negotiating for meaning), mille käigus jõutakse ühistele arusaamadele (Long 1983, 1996). Keeleõppe eesmärk ei ole mitte „ideaalse” keele selgeksõppimine, vaid funktsionaalse keeleoskuse saavutamine ehk suutlikkus tulla toime vajalike suhtlusülesannetega: saavutada oma eesmärgid ning kujundada head suhted kaaslastega (Larsen-Freeman 2007).

\section{Kaasahaaratuse olulisus teise keele omandamisel}

Oluline õppimise edukust määrav tegur on õppijate kaasahaaratus (ingl involvement) (vt nt Niemi, Vainiomäki 1999; Wagenaar jt 2003). Kaasahaaratuse rolli keeleomandamisel on uurinud Jan Hulstijn ja Batia Laufer (2001) ning näidanud, et uue sõnavara omandamise tõhusus sõnavaraõppe ülesannetes on seotud kognitiivsete protsessidega, mida ülesanne nõuab. Kaasahaaratus koosneb a) motivatsiooni komponendist, mis sisaldab vajadust (ingl need) uue sõna mõistmise järele, ja b) kognitiivsest komponendist, mis sisaldab sõna tähenduse leidmist (ingl search; näiteks sõnastikust) ja hindamist (ingl evaluation; näiteks kas sõnastikust leitud tähendus sobib nii verbaalsesse kui ka mitteverbaalsesse konteksti). Mida rohkem kognitiivseid protsesse on töös, seda suurem on kaasahaaratuse määr (ingl involvement load) ning seda tõhusam on uute sõnade esmane omandamine ja seda kauem sõnad mälus säilivad. See põhimõte kehtib nii eri tüüpi ülesannete kui ka eri keeleoskustasemete kohta ning on autorite arvates laiendatav ka grammatikale.

\subsection{Motivatsioon kaasahaaratuse tekitajana}

Seega algab kaasahaaratus motivatsioonist. Motivatsiooni osas erinevad esimese ja teise keele omandamine üsna palju. Esimest keelt omandaval lapsel on alati tugev motivatsioon, sest ta omandab keelt endale kallitelt inimestelt ja tal on eluline vajadus saada keelekogukonna liikmeks (Ellis 2003). Teise keele omandamisel on motivatsioon palju mitmekesisem ja keerukam. Mitte alati ei ole inimestel sisemist vajadust teist keelt omandada, vaid nad teevad seda pigem kohustuse tõttu (näiteks koolis või töötamise jaoks keeleeksami sooritamiseks; Centar 2018). Samuti ei õnnestu sugugi kõigil teise keele omandajail õppida keelt inimestelt, keda nad armastavad või kes neile väga meeldivad. Madal õpimotivatsioon võib mõjuda teise keele omandamist oluliselt aeglustavalt (Dörnyei 2001; Gardner 2007).

Sageli peetakse eesti keele kui teise keele õpimotivatsiooni eest vastutavaks õppijate kodu ja ühiskonda ehk kultuurikonteksti Robert Gardneri (2007) mudelis: eesti keele õppimise väärtuslikkust ja usku keele selgeks saamise võimalikkusse. Samas ei saa mingil juhul alahinnata hariduskonteksti osa õpimotivatsiooni kujundamises. Zoltán Dörnyei (1994) on näidanud õpitavate 
teemade, õppemeetodite ja -ülesannete ning õpetaja olulist osa õppijate õpimotivatsiooni kujundamisel. Seejuures on õpetaja roll määrav (Dörnyei, Csizér 1998; Chambers 1999) - just tema paneb aluse kõigele muule.

Õppeteemade motiveerivuse osas on peamine nende tähenduslikkus õppija jaoks (Tomlinson 2012). Tähenduslikud teemad on autentsed ehk pärit päriselust, mitte oppeotstarbel kunstlikult loodud. Tähenduslikud teemad puudutavad õppijaid isiklikult või käsitlevad üldisi maailma asju uudsel või intrigeerival moel (Stansbury 2011; Brophy 2004). Kui teemad on õppijate jaoks tähenduslikud ja kaasahaaravad, siis tahavad õppijad nende teemadega tegeleda, nende üle arutleda ja oma arvamust väljendada. Nii töötlevad nad õpitavat materjali sügavamalt ja omandavad selle tõhusamalt kui mittetähenduslike teemade korral (Tomlinson 2012).

Ka õppemeetoditel ja -ülesannetel on väga oluline roll õpimotivatsiooni kujundamises. Motiveerivamad on üldjuhul aktiivõppemeetodid ja päriselulised või päriselu realistlikult jäljendavad ülesanded. Need haaravad õppijaid tegevusse: nad saavad kõiges osaleda, mõelda, omavahel suhelda, õpitavat keelt eri olukordades kasutada (Mehisto jt 2010; Karm 2013; Brophy 2004). Tugeva motiveeriva mõjuga on vaheldusrikkus, mängulisus, ootamatus, huumor ja omavaheline suhtlemine (Hadfield 2010). Eri tüüpi aktiivõppemeetodite kasutamine tekitab õppijail õpitavaga palju eri liiki seoseid, mis aitavad õpitavat sügavamalt töödelda ja paremini omandada.

\subsection{Emotsioonide roll kaasahaaratuse tekitajana}

Emotsioonidel on õppetegevusse haaratusel samuti oluline roll. Negatiivsed emotsioonid kitsendavad inimese tähelepanuvälja ja soodustavad tähelepanu kontsentreerumist mingitele spetsiifilistele tendentsidele ehk vähendavad üldist tegevusse haaratust. Positiivsed emotsioonid (huvi, uudishimu, rõõm jt) aga laiendavad tähelepanuvälja ja annavad juurde ressursse täielikumaks tegevusse kaasahaaratuseks (Csikszentmihalyi 1990; Ryan, Deci 2000; Egbert 2003).

Kõige enam uuritud negatiivne emotsioon teise keele omandamisel on ärevus. See on paratamatult teise keele õppega kaasnev nähtus, sest teist keelt kõneldes on suur tõenäosus väljenduda ebatavaliselt, teha vigu ja jätta endast seega rumal mulje (Dörnyei 2001). Õppijate liigse ärevuse vähendamine ning positiivsete emotsioonide tekitamine on õpetaja üks peaülesandeid, et soodustada kaasahaaratust ja tõhusamat keeleõpet. Selle saavutamiseks peab õpetaja suutma kujundada psühholoogiliselt turvalise ja motiveeriva õpikeskkonna. Meeldiv ja innustav õpikeskkond tähendab nii füüsiliselt mõnusat keskkonda kui ka vaimselt turvalist atmosfääri. Head õpikeskkonda saab õpetaja teadlikult kujundada. Esiteks peab õpetaja ise olema sõbralik ja rõõmsameelne ning näitama kõigi suhtes välja positiivsust. Teiseks tuleb suunata õppijaid pidevalt koostööle eri kaaslastega. Kolmandaks on oluline õpetaja enda rollieeskuju õppijate keelekasutusse, vigadesse ning kaaslastesse humaanselt suhtumisel, lisaks tuleb vajaduse korral kehtestada ka vastavad grupinormid (Hadfield 2010; Brophy 2004). 
Positiivseid emotsioone saab õpetaja esile kutsuda õpiülesannete esitamise, käivitamise ja nende täitmise toetamisega. Ülesanded tuleks esitada ja käivitada nii, et need tekitaksid uudishimu ja tegutsemisrõõmu. Ülesannete täitmise ajal on õpetaja roll pidev jälgimine, vajaduse korral toetamine ja innustamine (Tomlinson 2012; Dörney, Csizér 1998). Jõukohane ülesanne on õppijate hetketasemest veidi eespool, et õppijad saaksid väljuda turvatsoonist ja nautida väljakutsega hakkamasaamise tunnet (Brophy 2004; Csikszentmihalyi 1997). Selleks peab õpetaja tundma keele arengurada ehk teadma, millised konstruktsioonid on millal jõukohased. Uuringud on näidanud, et ülesande raskus sõltub peamiselt sellest, kuidas õpetaja ülesannet läbi viib (Tharp, Gallimore 1988). Oluline on ka õpetaja seletuste ja tagasiside mõju õppijaile. Seletused ja tagasiside peavad olema esitatud õppijaile arusaadaval viisil ning positiivsel ja innustaval moel. See julgustab opppijaid uue keelega katsetama ja seda kasutades eksima, kartmata negatiivset tagasisidet.

Tunnis peaks valitsema rõõmus ja lõbus meeleolu ning kõik õppijad peaksid kogema edutunnet. Kui õppijad on tugevalt tegevusele motiveeritud ja kogevad selle käigus palju positiivseid emotsioone, võib parimatel hetkedel tekkida vootunne (ingl flow). See tähendab nii intensiivset kaasahaaratust käimasoleva tegevusega, et tekib sellesse imendumise ja igapäevaelu reaalsusest väljumise tunne (Csikszentmihalyi 1990; Egbert 2003).

\subsection{Kaasahaaratuse saavutamine mängustatud-improvisatsiooniliste óppetegevuste abil}

Üks tõhus kaasahaaratuse suurendaja õppeprotsessis on mängustamine (ingl gamification) - mänguelementide lisamine tavapäraselt mittemängulistele tegevustele (vt nt Sillaots 2016). Mängustamist mõtestas esmakordselt Nick Pelling 2002. aastal (2011) ning laiemalt kasutatavaks sai see termin 2010. aastal. Praegu kasutatakse mängustamist palju ärimaailmas, eriti turunduses ja juhtimises. Mängustamise element on näiteks ostude eest kleepsude kogumine ja selle eest kingituse saamine. Viimasel ajal on mängustamine aga üha enam populaarsust kogumas ka eri vanuses inimeste koolitamisel (Kim 2015).

Põhilised mängustamise mehhanismid tulevad psühholoogiast ja nende eesmärk on tekitada õppijais positiivseid emotsioone ja haarata nad sügavalt õppeprotsessi. Kõige sagedamini kasutatakse mängudes välist motivatsiooni tekitavaid elemente - erisuguseid võistluselemente ja auhindade jagamist. Tunduvalt tõhusamad on siiski sisemist motivatsiooni käivitavad mängustamise elemendid: võimalus tunda positiivseid emotsioone, olla loominguline, kuuluda gruppi, suhelda kaaslastega, naerda. Kõige olulisemad ja ilmtingimata vajalikud mängustamise elemendid on väljakutsed ja interaktiivsed tegevused, mida sooritatakse väljakutsetega toimetulekuks. Suur osa mängustamise elemente on tänapäeval seotud arvuti- või telefonirakendustega, kuid mitte ainult (Kim 2015). Mängustamine on võimas vahend, mis aitab muuta igasuguses õppeprotsessis vajaliku, kuid sageli tüütu kordamise köitvaks ja tähenduslikuks ning seega tõsta ka selle tõhusust. Mängustamise tulemus on tõhus areng ja samal ajal ka heaolutunne. 
Improvisatsioon ehk impro (ingl improvisation) on üks olulisemaid mänguelemente. Impro tähendab ootamatust, ettemääratuse puudumist. Inimene ei ole selleks valmistunud, mis juhtuma hakkab, kuid peab situatsiooniga ikkagi toime tulema. See sunnib teda võtma kasutusse oma loovuse ja loogika ning ülesandega toimetulek vallandab tugevad positiivsed emotsioonid. Algselt on impro olnud teatri alaliik - spontaanne komöödia, mis sünnib kohapeal, publiku silme all. Improteatri algatajad Viola Spolin ja Keith Jonstone on oma meetodi väljatöötamist alustanud just koolikeskkonnas ning liikunud sealt edasi teatrimaailma. Viimasel ajal on impromeetodid jõudnud jälle tagasi haridusse, sest need on end õigustanud, haarates tänapäeva õppijaid kaasa ja aidates nii õppeprotsessi tunduvalt tõhustada. ${ }^{1}$ Impromeetodid rikastavad traditsioonilist haridust. Mängustatud improtegevuste abil loovad õppijad enda jaoks õpitavate teemade ja tekstide tegelikud tähendused (vt Spolin 1986; Lobman, Lundquist 2007), sest nad elavad sisse tekstipõhistesse rollidesse ja suhtlevad neis päriselu lähedaselt. Lisaks on impromängud aktiivsed ja emotsionaalsed ning aitavad tekitada õppimissoovi ka neis õppijates, keda tavatunnid ei käivita piisavalt. Heas improtegevuses on väljakutsed osalejaile paraja raskusega ja võimaldavad areneda. Kui väljakutsed käivad üle jõu, tekib osalejail frustratsioon ja nad loobuvad mängimast. Kui väljakutsed on aga liiga kerged, tunnevad inimesed tüdimust ja võivad selle tõttu tegevuse pooleli jätta. Siinkohal on oluline roll õpetajal, kes kavandab õppetegevused vastavalt grupi ja selle iga liikme tasemele.

Mängustatus ja improvisatsioon sobivad eeldatavalt ka teise keele õppe tõhustamiseks ja rõõmsamaks muutmiseks, sest puudutavad keeleomandamise protsessi tuuma - tähenduse teket autentses suhtlusolukorras, mis on väga kaasahaarav. Lisaks arendavad improtegevused õppijate üldisi suhtlemisoskusi, mis on suhtlussituatsioonis edukaks toimimiseks sama vajalikud kui keelekonstruktsioonide valdamine. Nendeks oskusteks on keskendumisja tähelepanuvõime, suhtlemisjulgus, verbaalne ja mitteverbaalne eneseväljendusoskus, esinemisoskus, eneseteadlikkus, enda ja kaaslaste ideede aktsepteerimine, empaatia, loovus, spontaansus, intuitsioon, analüütiline ja kriitiline mõtlemine, probleemide lahendamine, aktiivne kuulamine jmt. Mängustatud tegevustel on seega suur potentsiaal õppijate kaasahaaramiseks ja õppimise tõhustamiseks. Samuti aitab mängustamine murda arusaama, et tõhus õppimine peab tingimata olema tõsine ja raske töö.

\section{Mängustatud-improvisatsiooniline eesti keele kui teise keele suhtluskursus}

Järgnevalt vaatlen juhtumianalüüsi põhjal, kuidas konstruktsioonide kasutuspõhise omandamise ja kaasahaaratuse olulisuse põhimõtted on realiseerunud täiskasvanute eesti keele kui teise keele mängustatud-improvisatsioonilisel keelekursusel „Juhan”. Kursuse on välja töötanud Mare Kitsnik ja Lyosha Razin ning kursust on mitteformaalse koolituse firmas GameClub läbi viinud Mare Kitsnik. Kursuse peamine sihtrühm on inimesed, kes on eesti keelt

\footnotetext{
${ }^{1}$ http://www.ruutu10.ee/blogi/improajalugu
} 
õppinud ja mitmed ka eksami sooritanud, aga kes sellele vaatamata ei suuda keelt igapäevaelus kasutada. Kursusel osalemiseks ei ole ette nähtud kindlat keeletaset, kuid kursuse programm on koostatud B1-tasemele ehk igapäevase suhtluskeele harjutamise jaoks. Üsna sageli osaleb rühmas ka mõni inimene, kes on alles hiljuti Eestisse kolinud ja kelle tase on umbes A1. Samuti osaleb kursusel inimesi, kes on juba sooritanud B2-eksami, kuid soovivad saada rääkimispraktikat ja -julgust. Kursuse pikkus on 20 kohtumist ehk 53 akadeemilist tundi. Kohtumised toimuvad kaks korda nädalas õhtuti kella 18-20 (120 minutit ilma vaheajata). Kursused on toimunud alates 2016. aasta sügisest ja 2018. aasta lõpu seisuga on kursuse lõpetanud kümme õpperühma. Keskmine õpperühma suurus on 12-15 inimest.

Kursuse mõju esialgses analüüsis olen kasutanud enda kui õpetaja tunnijärgselt kirja pandud vaatlusandmeid ning kursusel osalenute tagasisideküsitluse vastuseid. Osas 3.1 arutlen õppijate kaasahaaramise põhimõtete üle, osas 3.2 paraja väljakutse ja toetuse üle kursusel ning osas 3.3 keelekonstruktsioonide arengu üle kursuse käigus.

\section{1. Õppijate kaasahaaramise põhimõte}

Alates kursuse algusest pööratakse suurt tähelepanu kõigi õppijate aktiivsesse tegevusse kaasahaaramisele. Selleks on loodud hea füüsiline õpikeskkond (vaipkattega põrand, laudade puudumine, mugavad kergelt liigutatavad toolid) ning turvaline ja positiivne vaimne õhkkond (vt lähemalt osas 3.2). Kõik kursusel toimuvad tegevused on mängulised ning kursus on vaheldusrikas, sama tegevust üldjuhul ei korrata. Enamasti tegutsetakse kõik korraga paarides või kolme-neljakaupa rühmades ja suhtluspartnereid sageli vahetades. Tegevusi, milles osaleb vaid paar inimest ja ülejäänud on pealtvaataja rollis, on vähe (enamasti vaid mõne mängu esmased demonstratsioonid).

Kohtumised on üles ehitatud nii, et sujuvalt liigutakse lihtsamatelt ja lühematelt tegevustelt nõudlikumate ja pikemate suunas. Iga kohtumine algab kiire füüsilise soojendusmänguga (nt Laste-Aliase piltide kujutamine pantomiimiga), mille eesmärk on päevapingetest vabaneda ning mängukeskkonda sisse elada. Järgneb sõnaline soojendusmäng (nt kahekesi assotsiatsiooniketi moodustamine), mis aitab inimestel eesti keele üles soojendada.

Õpetaja kommentaar: Assotsiatsiooniketis peavad paarilised ütlema esimese sõna, mis neil mingi sõnaga pähe tuleb, ja nii ketti jätkama, nt piim - lehm sarved - kaljukits jne. Harjutus soojendab üles inimeste teadvuses oleva eesti keele konstruktsioonivõrgustiku. Mulle meeldib eriti, et siin pole õigeid ja valesid vastuseid, mis vähendab inimeste ärevust ja kartust eksida.

Edasi järgneb ühe olulise konstruktsioonitüübi lühitutvustus ja seejärel selle mänguline harjutamine. Käskiva kõneviisi konstruktsioone drillitakse näiteks üksteisele käske andes ja neid reaalselt või kujuteldavalt täites. Täismineviku konstruktsioone harjutatakse mänguga „Mina olen detektiiv”, milles tuleb küsimuste abil leida mõistatusliku loo lahendus. 
Õpetaja kommentaar: Kursuse ülesehituses on kindel süsteem - harjutatavad konstruktsioonid on valitud nende olulisuse järgi B1-taseme õppijaile ning harjutamiseks on loodud tegevused, milles konstruktsioonid esinevad oma loomulikes tähendustes ja suhtlusfunktsioonides. Situatsioonid on seejuures aktiivsed, loovad ja lõbusad.

Õppija kommentaar: Me tegutsesime nagu mingis imelises maailmas, mängisime, naersime kogu aeg, tegime palju nalja, lamasime põrandal, joonistasime, mõtlesime asju välja. Ja seda kõike eesti keeles!

Kohtumise teises pooles on osalejad juba üles soojenenud ning liigutakse vabamat suhtlust nõudvate improdialoogide, lugude ja muude suhtlusmängude juurde, mis imiteerivad tegelikus elus ettetulevaid suhtlussituatsioone looval ja lõbusal moel. Teemad ja rollid tekivad osalejate loominguna kohapeal ning on seotud mingi intriigi või naljaka nüansiga, mis suhtluse käivitab.

Õpetaja kommentaar: Kui inimesed vabanevad hirmudest, muutuvad nad väga loovaks. Nii on välja pakutud dialoogiteemasid „Stjuuardess ja lennureisija, kes on pahane, et talle kana ei serveerita”, „Ilukirurg ja tema pettunud patsient”, „Rõõmus laps ja tüdinud isa loomaaias”.jpm.

Lisaks intrigeerivale teemale on oluline dialoogi käivitav formaat. Näiteks improformaadis „Tähestik” peavad dialoogis osalejad vestlema nii, et kui esimene osaleja alustab oma vestlusvooru tähega $K$, siis teine peab vastust alustama tähestikus järgmise ehk L-tähega jne. Selline lisatingimus toob osalejate teadvusest esile ootamatuid sõna- ja fraasikombinatsioone ning tekitab pidevalt pöördeid, mis teeb dialoogi ettearvamatuks, lõbusaks ja huviga jälgitavaks. Õppijad ei tea kunagi ette, mis situatsioonidesse nad satuvad, kuidas situatsioon areneb ja mida nad täpselt rääkima hakkavad. See käivitab nende ajutegevuse ning tekitab sisemise motivatsiooni keelt kasutada.

Õpetaja kommentaar: On väga tore jälgida, kuidas täiesti tavalised inimesed loovad selliseid dialooge, et neid kuulates ei saa kuidagi tõsiseks jääda. Olen ka märganud, et mõnigi kord osutuvad keeleliselt mitte kõige tugevamad õppijad sellistes dialoogides väga andekaks. Oluline on, et mina dialoogide sisusse ei sekku. Õppijaile on vaja anda aega ja rahu, et nende mõte saaks jooksma hakata.

Õppija kommentaar: Siin su aju kogu aeg töötab. Sa ei tea, mis sinuga järgmine hetk toimub. Olin president ja viie minuti pärast olin koristaja. Siin kõik kuulavad üksteist, sest see on huvitav, mitte nagu tavalisel kursusel, kus keegi teist ei kuula. Ma ei ole kunagi varem eesti keeles nii palju rääkinud ja nii palju mõelnud.

Tänu aktiivsetele, põnevatele ja loovatele mängulistele tegevustele möödub 120-minutiline kohtumine kiiresti. Üldjuhul on inimesed tegevustesse nii kaasa haaratud, et ei märka, kuidas aeg möödub. Võib öelda, et parimail hetkil 
tekib vootunne. Pärast kohtumist on inimestes palju rõõmu, hasarti ja energiat.

Õppija kommentaar: Kartsin juba, et kohtumine lõpeb. Olin juba nii kurb. Aga siis selgus õnneks, et olin valesti arvestanud ja meil on pool tundi veel.

Õppija kommentaar: Pärast kursust tunnen, et läheks kohe tööle tagasi, nii palju energiat on.

\subsection{Paraja väljakutse ja toetamise põhimõte}

Mängulised tegevused pakuvad õppijaile väljakutset - inimesed peavad oma turvatsoonist väljuma, tegutsema ja kasutama keelelisi vahendeid, mis on nende jaoks uued või mille kasutamises pole nad varem edukad olnud. Kursus tervikuna ja iga kohtumine üksikuna on kavandatud nii, et liigutakse vähenõudlikematest ja rohkem toetatud tegevustest keerukamate ja vabamat keelekasutust nõudvate suunas. Samuti saavad keeleõppijad (eriti kursuse esimeses pooles) igal kohtumisel töölehe fraasidega, mida võivad soovi korral järgnevates mängudes kasutada. Samas ei pruugi tugevama tasemega õppijad töölehte tarvitada.

Igal kohtumisel tegeldakse veidi põhjalikumalt mõne konstruktsioonitüübiga, mis on sellel arenguetapil vajalik ja jõukohane. Seletusi antakse lihtsas eesti keeles ja vajaduse korral ka õppijate emakeeles. Konstruktsioonide tutvustamise ja kohese mängustatud harjutamise peaeesmärk on muuta vastav konstruktsioonitüüp óppijate jaoks esilduvamaks ja kasutuses automaatsemaks. Kõigi mänguliste tegevuste juhised antakse selgelt ja lühidalt ning tegevused näidatakse üldjuhul ka ette.

Õppija kommentaar: Kõik tegevused toimuvad kerges õhkkonnas, mis ei meenuta üldse kooliajast vastikuks muutunud tuupimist.

Vabamat keelekasutust nõudvad eri tüüpi impromängud on mitmekesised ning pakuvad varieerimisvõimalusi. Nii saavad sama ülesannet täita tugevama tasemega õppijad keerukamal viisil ning madalama tasemega õppijad vähemnõudlikul kujul.

Õppija kommentaar: Õppisin palju teisi, parema keeleoskusega inimesi kuulates.

Õppija kommentaar: On huvitav, et iga grupiliige rikastab õppeprotsessi oma sõnade ja oma teemadega, mis võimaldab saada üsna palju uut infot.

Kohtumisel hoitakse kogu aeg positiivset ja rõõmsat meeleolu. Õpetaja on alguses ise õppijatele rollimudeliks, näidates oma käitumisega ette, kuidas reageerida kaaslaste jutule huvitatult ja keelelistele ebatäpsustele rahulikult. See aitab inimeste ärevust ja hirme alandada. 
Õppija kommentaar: See õpetaja oskab niimoodi su vigu parandada, et sa tunned, et sul tulebki välja, et oskadki eesti keelt.

Õppija kommentaar: Eraldi tahaks tänada õpetajat, kes nii pehmelt lõi kerge ja heasoovliku õhkkonna, alati aitas, ütles ette ja lihtsalt eemaldas hirmu, et keegi hakkab kritiseerima vigade pärast.

Oluline eesmärk on ka arendada õppijate suhtlemisjulgust ja loovust: oskust oma olemasoleva keelepagasiga elus vajaduse korral hakkama saada.

Õppija kommentaar: Olin Eestis elanud aasta ja oskasin eesti keeles öelda vaid vabandust ja palun. Selle kursuse kolmandal nädalal seletasin müüjale, et mul on vaja osta koitõrjevahendit. Kui olin öelnud fraasi „sööb riided”, sai müüja must kohe aru. Peamine ongi see, et hirm rääkida ja hirm, et sind ei mõisteta, oli kadunud kahe nädalaga!

\subsection{Keelekonstruktsioonide loomuliku arenemise põhimõte}

Kursusel osalejate keeleline pädevus kursuse alguses on erisugune. Osal on märgata mitmesuguseid teoreetilisi teadmisi, mida nad on varasematelt kursustelt omandanud, kuid mida nad praktilises suhtluses kasutada ei suuda. Teisel osal teoreetilised teadmised puuduvad või on väga vähesed. Kursusel ei õpita grammatikat teoreetiliselt ega tehta ühtegi kirjalikku harjutust.

Õpetaja kommentaar: Konstruktsioone käsitleme alati vormi-tähenduse-kasutuse komplektina, seejuures pöörame tähelepanu tegelikus elus sageli vajalikele funktsioonidele, näiteks tingiva kõneviisi puhul harjutame kindlasti viisakuse funktsiooni.

Konstruktsiooni mängulise drillimise etapis saavad õppijad kätte konstruktsiooni õiged kujud, näiteks paberlipikud, millele on kirjutatud fraasid lihtmineviku vormis (nt ma kallistasin sõpra, ma sõitsin lennukiga, ma hilinesin kohtumisele). Mängides kasutatakse neid õiges vormis konstruktsioone korduvalt.

Õppija kommentaar: Mulle jääb mõni fraas meelde just seoses kaaslasega, kes seda näiteks pantomiimiga näitas.

Kuigi konstruktsioonide mänguline drillimine on kaasahaarav ja kasulik, hakkavad konstruktsioonid päriselt arenema siiski alles vaba suhtluse mängudes. Improvisatsioonilised igapäevaelu tekstid ei ole küll täiesti autentsed, kuid autentsele lähedased. Neid tekste luues tekib õppijatel kogu aeg vajadus keeles sagedamini esinevate konstruktsioonide järele. Seega saavad nad just neid sageli kuulda, kasutada ning soovi korral üles kirjutada. Konstruktsioonid on ka alati seotud konkreetse suhtlussituatsiooniga, kinnistudes nii osalejate teadvuses vormi ja tähenduse terviküksusena. Seejuures tuleb sisendkeel 
nii õpetajalt kui ka osalejailt endilt - ka õppijakeel on autentne sisendkeel, mis muutub arenedes üha paremaks.

Õpetaja kommentaar: Kui alguses teeme konstruktsioonid mängulise drillharjutusega esilduvaks, siis ei tähenda see veel kaugeltki omandamist. Kui aga korduvalt on vaja minevikuvormi näiteks improjuttudes kasutada, et enda soovitud tähendust edasi anda, on märgatav, kuidas see konstruktsioon järkjärgult areneb ja hakkab mingil hetkel juba ilma mõtlemata välja tulema. See ongi konstruktsiooni tegelik omandamine.

Õppija kommentaar: Nüüd ma julgen vigadega rääkida. Ma tean, et minust saadakse aru ja küll ma hakkan varsti õigesti ka ütlema. Ütlen ükskord valesti. Ütlen teine kord valesti ja juba tunnen ise, et oli valesti. Ja kolmas kord tulebki juba õigesti.

Õppija kommentaar: Ootasin seda kursust väga ja olen väga tänulik. Hakkasin rääkima palju julgemalt ja paremini.

\section{Kokkuvõte}

Õppijate kommentaar: See kursus erineb varasematest kardinaalselt. See oli lõbus, huvitav, ebatavaline, ootamatu, vaba, liikuv, loominguline, seikluslik, suurepärane!

Õppija kommentaar: Õpetaja ütles kohe alguses, et keelt õppida on superhuvitav ja et kõik hakkavad rääkima. Ja tal oli õigus. Nii läkski - kõik hakkasid rääkima.

Õppija kommentaar: Ma arenesin siin kursusel ka isiksusena. Kui sa mängid, siis sinuga hakkavad juhtuma imelikud asjad, mida kunagi varem ei juhtunud! Aitäh!

Õppija kommentaar: Aitäh, et tegite õppimisest rõõmu! Mul on nüüd suur hasart eesti keelt igal pool märgata ja kasutada proovida.

Eesti keel teise keelena areneb nagu kõik muudki keeled tõhusalt ja loomulikult siis, kui keeleõppijad saavad suuremahulise autentse keelelise sisendi ja võimaluse ise keelt aktiivselt kasutada. Kui inimesed vabanevad keeleõppega seotud hirmudest ja stressist ning tunnevad, et nendega tahetakse suhelda ja neist saadakse aru, siis julgevad ja tahavad nad palju keelt kuulda ja kasutada ning nende keel areneb. Teise keele hea õpe ei tekita õppijais kartust ega suhtlusbarjääri, vaid muudab keeleõppe rõomsaks, aktiivseks ja loomulikuks ning toetab õppijate motivatsiooni. Keeleõppes tasuks julgelt proovida rohkem mängustatud-improvisatsioonilisi meetodeid, kasutades neid süsteemse kursuse raames. Need võimaldavad intensiivset ja tähendusrikast keelekasutuspraktikat, muudavad keeleõppe õppijaile kergeks ja lõbusaks ning tekitavad hasarti keeleõpet autentses keelekeskkonnas jätkata. 


\section{Kirjandus}

B r o phy, Jere 2004. Motivating Students to Learn. Mahwah-New Jersey-London: Lawrence Erlbaum Associate.

B y bee, Joan 2000. Lexicalization of sound change and alternating environments. - Language Acquisition and the Lexicon. (Papers in Laboratory Phonology V.) Toim Michael B. Broe, Janet B. Pierrehumbert. Cambridge: Cambridge University Press, lk 250-268.

CEFR 2007 = Euroopa keeleõppe raamdokument. Õppimine, õpetamine ja hindamine. Tartu: Haridus- ja Teadusministeerium.

Centar 2018 = Eesti keelest erineva emakeelega täiskasvanute eesti keele õpe lõimumis- ja tööhõivepoliitikas: kvaliteet, mõju ja korraldus. Tallinn: Eesti Rakendusuuringute Keskus Centar, Tallinna Ülikool.

Chambers, Gary N. 1999. Motivating Language Learners. Clevedon: Multilingual Matters.

Csiks zentmih alyi, Mihaly 1990. Flow: The Psychology of Optimal Experience. New York: Harper and Row.

Csikszentmihalyi, Mihaly 1997. Intrinsic motivation and effective teaching: A flow analysis. - Teaching Well and Liking It: Motivating Faculty to Teach Effectively. Toim James L. Bess. Baltimore: The Johns Hopkins Press, lk 72-89.

Clark, Eve V. 1978. Discovering what words can do. - Papers from the Parasession on the Lexicon, Chicago Linguistics Society, April 14-15, 1978. Toim Donka Farkas, Wesley M. Jacobsen, Karol W. Todrys. Chicago: Chicago Linguistics Society, lk 34-57.

Croft, William 2001. Radical Construction Grammar: Syntactic Theory in Typological Perspective. Oxford: Oxford University Press.

Dör nyei, Zoltán 1994. Motivation and motivating in the foreign language classroom. - Modern Language Journal, kd 78, nr 3, lk 273-284.

Dörnyei, Zoltán 2001. Motivational Strategies in the Language Classroom. Cambridge: Cambridge University Press.

Dörnyei, Zoltán, Csizér, Kata 1998. Ten commandments for motivating language learners: Results of an empirical study. - Language Teaching Research, kd 2, nr 3, lk 203-229.

E g bert, Joy 2003. A study of flow theory in the foreign language classroom. - The Modern Language Journal, kd 87, nr 4, lk 499-518.

Ellis, Nick C. 2002. Frequency effects in language acquisition: A review with implications for theories of implicit and explicit language acquisition. - Studies in Second Language Acquisition, kd 24, nr 2, lk 143-188.

Ellis, Nick C. 2003. Chapter 4: Constructions, chunking and connectionism. The emergence of second language structure. - The Handbook of Second Language Acquisition. Toim Catherine J. Doughty, Michael H. Long. Oxford: Blackwell Publishing, lk 63-103.

Ellis, Nick C. 2005. Introduction to Part 1: Acquisition. - Handbook of Bilingualism: Psycholinguistic Approaches. Toim Judith F. Kroll, Annette M. B. de Groot. Oxford: Oxford University Press, lk 3-7.

Ellis, Nick C. 2013. Second Language Acquisition. - The Oxford Handbook of Construction Grammar. Toim Thomas Hoffmann, Graeme Trousdale. Oxford: Oxford University Press, lk 365-378. 
Ellis, Nick C., Ferreir a - Junior, Fernando 2009. Construction learning as a function of frequency, frequency distribution, and function. - Modern Language Journal, kd 93, nr 3, lk 370-385.

Ellis, Nick C., Larsen-Freeman, Diane 2009. Constructing a second language: Analyses and computational simulations of the emergence of linguistic constructions from usage. - Language Learning, kd 59, nr S1, lk 93-128.

E 11 is, Nick C., S a g a r r a, Nuria 2013. From seeing adverbs to seeing verbal morphology: Language experience and adult acquisition of L2 tense. - Studies in Second Language Acquisition, kd 35, nr 2, lk 261-290.

English Profile. http://www.englishprofile.org (7. I 2019).

Eskildsen, Søren Wind 2008. Constructing a Second Language Inventory: The Accumulation of Linguistic Resources in L2 English. (PhD dissertation.) Odense: Institute of Language and Communication University of Southern Denmark.

Gardner, Robert C. 2007. Motivation and second language acquisition. - Porta Linguarum, nr 8, lk 9-20.

Goldberg, Adele 1995. Constructions. A Construction Grammar Approach to Argument Structure. Chicago: The University of Chicago Press.

Gold ber g, Adele 2003. Constructions: A new theoretical approach to language. Trends in Cognitive Sciences, kd 7, nr 5, lk 219-224.

Hadfield, Jill 2010. Rühmadünaamika võõrkeeletunnis. Tlk Ursula Erik. Tallinn: Argo.

H a r m er, Jeremy 2007. How to Teach English. Harlow: Pearson Education Ltd.

Hulstijn, Jan H., L a u fer, Batia 2001. Some empirical evidence for the involvement load hypothesis in vocabulary acquisition. - Language Learning, kd 51, nr 3, lk 539-558.

Kaivapalu, Annekatrin 2005. Lähdekieli kielenoppimisen apuna. (Jyväskylä Studies in Humanites 44.) Jyväskylä: Jyväskylän yliopisto.

Ka r m, Mari 2013. Õppemeetodid kõrgkoolis. Tallinn: SA Archimedes. http://www. digar.ee/id/nlib-digar:121275 (7. I 2019).

Ki m, Bohyun 2015. Understanding Gamification. (Library Technology Reports, kd 51, nr 2.) Chicago: American Library Association.

Kitsnik, Mare 2018. Iga asi omal ajal: eesti keele B1- ja B2-taseme verbikonstruktsioonid keeleoskuse arengu näitajana. (Humanitaarteaduste dissertatsioonid 43.) Tallinn: Tallinna Ülikool.

Larsen-Freem a n, Diane 1997. Chaos/complexity science and second language acquisition. - Applied Linguistics, kd 18, nr 2, lk 141-165.

Larsen-Freeman, Diane 2007. Reflecting on the cognitive-social debate in second language acquisition. - The Modern Language Journal, kd 91, nr S1, lk $773-787$.

Lobman, Carry, Lundquist, Matthew 2007. Unscripted Learning: Using Improv Activities Across the K-8 Curriculum. New York: Teachers College Press.

L o n g, Michael H. 1983. Native speaker/non-native speaker conversation and negotiation of comprehensible input. - Applied Linguistics, kd 4, nr 2, lk 126-141.

Long, Michael H. 1996. The role of linguistic environment in second language acquisition. - Handbook of Second Language Acquisition. Toim William C. Ritchie, Tej K. Bhatia. San Diego: Academic Press, lk 413-468. 
M a c Wh in ney, Brian 2002. The Competition Model: The Input, the Context, and the Brain. (Paper 219.) Pittsburgh, PA: Carnegie Mellon University, Department of Psychology.

Ma cW hin n ey, Brian 2004. A unified model of language acquisition. - Handbook of Bilingualism: Psycholinguistic Approaches. Toim Judith Kroll, Annette de Groot. Oxford: Oxford University Press, lk 49-67.

Martin, Maisa, Mustonen, Sanna, Reiman, Nina, Seilonen, Marja 2010. On becoming an independent user. - Communicative Proficiency and Linguistic Development: Intersections Between SLA and Language Testing Research. (Eurosla Monographs Series 1). Toim Inge Bartning, M. Martin, Ineke Vedder. EUROSLA, lk 57-80.

Mehisto, Peeter, Marsh, David, Frigols Martín, María Jesús, Võlli, Kai, A s s e r, Hiie 2010. Lõimitud aine- ja keeleõpe. Tallinn: Integratsiooni ja Migratsiooni Sihtasutus Meie Inimesed.

Must on en, Sanna 2015. Käytössä kehittyvä kieli. Paikat ja tilat suomi toisena kielenä oppijoiden teksteissä. (Jyväskylä Studies in Humanities 255.) Jyväskylä: Jyväskylän yliopisto.

Ni e mi, Päivi M., V a i n i o m äki, Paula T. 1999. Medical students' distress, coping and achievement strategies during the preclinical years. - Teaching and Learning in Medicine, $\mathrm{nr}$ 11, lk 125-134.

Nin i o, Anat 1999. Pathbreaking verbs in syntactic development and the question of prototypical transitivity. - Journal of Child Language, kd 26, nr 3, lk 619-653.

Pa avola, Vilja 2008. Haluatko menna muunkansa kalastaman? Verbiketjujen kehkeytyminen suomi toisena kielenä -oppijoiden kielessä. (Suomen kielen pro gradu-tutkielma.) Jyväskylä: Jyväskylän yliopisto.

Pelling, Nick 2011. The (short) prehistory of „gamification”. http://nanodome. wordpress.com/2011/08/09/the-short-prehistory-of-gamification (7. I 2019).

Pinker, Steven 1989. Learnability and Cognition: The Acquisition of Argument Structure. Cambridge, MA: Bradford Books.

Ryan, Richard M., Deci, Edward L. 2000. Self-determination theory and the facilitation of intrinsic motivation, social development, and well-being. - American Psychologist, kd 55, nr 1, lk 68-78.

Schmidt, Richard 2001. Attention. - Cognition and Second Language Instruction. Toim Peter Robinson. Cambridge: Cambridge University Press, lk 3-32.

Seilonen, Marja 2013. Epäsuora henkilöön viittaaminen oppijansuomessa. (Jyväskylä Studies in Humanities 197.) Jyväskylä: Jyväskylän yliopisto.

Silla ots, Martin 2016. Creating the Flow: The Gamification of Higher Education Courses. (Dissertations on social sciences 107.) Tallinn: Tallinn University.

Spad a, Nina 1997. Form-focussed instruction and second language acquisition: A review of classroom and laboratory research. - Language Teaching, kd 30, nr $2,1 \mathrm{k} 73-87$.

Spolin, Viola 1986. Theater Games for the Classroom. A Teacher's Handbook. Evanston, Illinois: Northwestern University Press.

Stansbury, Meris 2011. Five things students say they want from education. eSchool News, 28. VII. http://www.eschoolnews.com/2011/07/28/five-things-students-say-they-want-from-education (7. I 2019).

Zipf, George Kingsley 1949. Human Behavior and the Principle of Least Effort. Addison: Wesley Press. 
Tharp, Roland G., Gallimore, Ronald G. 1988. Rousing Minds to Life. Teaching, Learning, and Schooling in Social Context. Cambridge: Cambridge University Press.

Tom a s ello, Michael 2000. First steps toward a usage-based theory of language acquisition. - Cognitive Linguistics, kd 11, nr 1-2, lk 61-82.

Tom asello, Michael 2003. Constructing a Language: A Usage-Based Theory of Language Acquisition. Cambridge, MA: Harvard University Press.

To m lin s o n, B. 2012. Materials development for language learning and teaching. - Language Teaching, kd 45, nr 2, lk 143-179.

Wagenaar, A., Scherpbier, A. J., Boshuizen, H. P.A., Van der Vleuten, C. P. M. 2003. The importance of active involvement in learning: A qualitative study on learning results and learning processes in different traineeships. Advances in Health Sciences Education, nr 8, lk 201-212.

Mare Kitsnik (snd 1962), PhD, Tartu Ülikool, eesti ja üldkeeleteaduse instituut, rakenduslingvistika osakond, eesti keele võõrkeelena didaktika vanemteadur (Jakobi2-437, 51005 Tartu), mare.kitsnik@ut.ee

\section{Learning Estonian as a second language - hard work or easy fun?}

Keywords: Estonian as a second language, language acquisition, language constructions, usage-based approach, gamification

The article tries to answer the question whether Estonian as a second language can be learned in a way that is not only effective, but also easy and fun. First, the principles of second language development are discussed. This discussion is based on the view that language consists of constructions - linguistic units in which words and grammar are inextricably intertwined and whose form and meaning form a whole (e.g. I do not know) (Goldberg 1995; Croft 2001). Constructions develop in the learner language on a usage-based way (Eskildsen 2008; Martin et al. 2010; Mustonen 2015; Kitsnik 2018). This means that to acquire a second language a person needs much input from an authentic language environment, as well as a lot of opportunities to try and use the language.

To support the teaching of a second language in language classes, there is a need to use as authentic linguistic inputs as possible and create a lot of motivating ways to use the language in realistic situations. To achieve these goals the innovative methodology of gamification seems very suitable. Using this methodology learners are really involved in exciting situations, which needs a lot of improvisation and offers challenges. Active and realistic activities, a good atmosphere and support make language learning easy and allow constructions to develop effectively. Joint performing of fun tasks give learners a lot of positive emotions and make language learning fun.

Mare Kitsnik (b. 1962), PhD, University of Tartu, Department of Applied Linguistics, Senior Research Fellow in Estonian as Foreign Language (Jakobi 2-437, 51005 Tartu), mare.kitsnik@ut.ee 